\title{
Growth and gonadal maturation of Keeled mullet, Liza carinata, (Valenciennes, 1836) cultured at different salinities
}

\author{
Kamal F. Elboray, Magdy M. EL-Halfawy, Waheed F. Mahmoud, \\ Amal M. Amin, Amal M. Ramadan and Yousry A. Soliman \\ National Institute of Oceanography and Fisheries, Suez, Egypt. \\ e.mail: elhalfawy2006@yahoo.com
}

\begin{abstract}
The growth experiment was conducted in fish culture outdoor cement ponds (5X4X1.2) under controlled conditions and filled with water $\left(20 \mathrm{~m}^{3}\right)$. The experiment was carried out through 210 days. Every day, about 15-20\% of water content was replaced to maintain water quality. Fish in all ponds were fed about $5 \%$ of total fish weight on artificial diet contains $25 \%$ fish meal. Experimental salinities $(5,15,25$, and $40 \%$ ) in four ponds (triplicate design) were obtained by diluting sea water with dechlorinated tap water (by passing through active charcoal). Fish at salinities $5 \%$ and $40 \%$ exhibited greater growth in length $(\mathrm{cm}) 10.77 \pm 0.097,11.39 \pm 0.088$ and weight $(\mathrm{gm}) 12.3 \pm 0.319,15.02 \pm 0.44$, respectively $(\mathrm{P}<0.05)$. Fishes at salinities of 15 $\% o$ and $25 \%$ represented lower growth in length $9.15 \pm 0.23,9.1 \pm 0.10$ and weight $7.41 \pm 0.53,7.83 \pm 0.29$, respectively $(\mathrm{P}>0.05)$. It was found that salinity does not affect significantly the condition factor of the individuals. Condition factor was ranging from 0.93 to 1.03 and there were no significant differences $(\mathrm{P}<0.05)$ between fish that had been subjected to different salinity treatments. Gonad somatic index (GSI) was significantly influenced by salinity $(\mathrm{P}>0.05)$. The GSI for both males and females have nearly the same fluctuation trends which reached to the maximum level at salinity of $40 \%$ for both sexes; 8.9 for female and 2.1 for male. The highest coefficient "b" of length-weight relationship were $2.839,2.847$ for fishes at salinities $40 \%$ and $5 \%$, respectively they closed to 3 it is indicated that isometric growth. The gonad maturation of salinity $5 \%$ reached to ripe stage for male and yolk vesicle stage for female but it reached to ripe stage at salinity $40 \%$ o for both sex. These results suggest that Liza carinata is a suitable candidate for low salinity brackish water aquaculture. This could lead to significant cost savings when rearing fish inland.
\end{abstract}

Keywords: Liza carinata, salinity, growth, gonadal maturation

\section{INTRODUCTION}

Family Mugilidae is widely spread and representing an important species for cultivation in fish farms. Liza carinata commonly inhabit tropical and warmtemperate estuaries (Eisawy et al., 1974; McDowall, 1988; Blaber, 1997; Pombo et al., 2005). Laffaille et al., 1998, 2002; Torras et al., 2000; Cardona, 2001; Almeida, 2003 indicated that mugilidae play a crucial ecological role where this fish community appears to be particulate organic matter transporter and could play a significant role in the global energy budgets of environment. Although this species always spawn at sea, they are highly euryhaline and thrive in a wide range of salinities (McDowall, 1988). Due to their euryhalinity, they are often stocked in brackish coastal lagoons to improve fisheries yields (Ravagnan, 1992) and are introduced into fresh water lakes and reservoirs to create new fisheries (Ben Tuvia et al., 1992). Growth of euryhaline species is often negatively affected by salinity because the 
energy used for osmoregulation is not available for growth (Brett, 1979; Wootton, 1990). Consequently, this species has an optimum salinity level at which the growth rate is highest and the cost of osmoregulation lowest, which may affect fish distribution in the wild (Blaber, 1997).

To determine the aquaculture potential of a species, a series of growth trials should be undertaken to help define the culture conditions for best growth (Deacon, 1997). Several interacting variables, such as temperature, light intensity, feeding intensity and feeding frequency can moderate fish growth (Brett, 1979). Salinity has been chosen for this study as it influences development and growth in marine fish (Iglesias et al., 1987; Boeuf and Payan 2001 \& Resley et al., 2006) through its effect on metabolic rate, food intake and food conversion ratio (FCR). For example, in a study testing a range of salinities on juvenile Atlantic croaker, Micropogonias undulatus, growth was improved at salinities below 35\%o, with fastest growth at 5\%o (Peterson et al. 1999). Low salinity may reduce metabolic cost for homeostasis and ionic osmoregulation (Morgan and Iwama, 1996 \& Woo and Kelly, 1999), for example in sea bream, Sparus sarba, and Atlantic cod, Gadus morhua (Woo and Kelly, 1999).

Several studies investigated the accumulatory response of marine fish species to salinity regimes lower than full-strength seawater. Those authors such as Lambert et al., (1994), Gaumet et al., (1995), Woo and Chung (1995) and Imsland et al., (2001\& 2003) indicated to the growth rate of marine fish species was better at lower salinities than in full-strength seawater. The present study was conducted to compare growth and gonad maturation of Liza carinata at four different salinities throughout farming period.

\section{MATERIAL AND METHODS}

Liza carinata fry were collected from Suez Bay. They were transferred to the National Institute of Ocenography and Fisheries, Suez branch. The growth experiment was conducted in fish culture outdoor cement ponds (4X5X1.2) under controlled conditions and filled with water $\left(20 \mathrm{~m}^{3}\right)$. Every day, about $15-20 \%$ of water content was replaced to maintain water quality. Fish in all ponds were fed about $5 \%$ of total fish weight on artificial diet contains $25 \%$ fish meal. Experimental salinities $(5,15$, 25 , and $40 \%$ ) in four ponds (triplicate design) were obtained by diluting sea water with dechlorinated tap water (by passing through active charcoal). Temperature, $\mathrm{pH}$, salinity and dissolved oxygen (DO) concentrations were measured three times a week in all ponds. The dissolved oxygen was measured according to (Winkler, 1976). Salinity was adjusted using a Metter Toledo conductivity meter and the $\mathrm{pH}$ was measured using a Jenway $3505 \mathrm{pH}$ meter. Samples for dissolved inorganic nutrient (Ammonia, Phosphate, Nitrate and Nitrite) analyses were collected weekly and analyzed immediately according to Parsons et al. (1984) using a Beckman DU-6 UV VIS spectrophotometer with blanks and standards.

Liza carinata fingerlings $\left(25 \mathrm{fish} / \mathrm{m}^{3}\right)$ was used in this experiment with mean initial total length $4.3 \pm 0.7 \mathrm{~cm}$; mean initial weight $0.6 \pm 0.15 \mathrm{~g}$. At the end of the study, all fish were sacrificed to determine sex and maturity stage. Gonads were fixed in Bouin's solution for 24 hours and transferred to alcohol (70\%). After conventional histological processing, sections of $5 \mu \mathrm{m}$ thick were stained with haematoxylin and eosin and observed under a light microscope (Leica DM500). Assessment of gonadal development followed the description of Elhalfawy et al. (2007). 
The condition factor $(\mathrm{CF})$ was calculated using the formula: $\mathrm{CF}=\mathrm{W} / \mathrm{L}^{3} \mathrm{X} 100$

Where $\mathrm{w}=$ Total weight in $\mathrm{g}$ and $\mathrm{L}=$ total length in $\mathrm{cm}$.

Length/weight relationship was calculated as $\mathrm{W}=\mathrm{a} \mathrm{Lb}$, where $\mathrm{a}$ is the constant and $\mathrm{b}$ is the exponent of growth.

Gonadosomatic index (GSI) was calculated as GSI = G.wt / T.wt X 100

Where G. wt = gonad weight and T.wt. = Total weight

Where appropriate, one-way analysis of variance followed by Tukey's test was used, with significance level accepted at $P=5 \%$.

\section{RESULTS AND DISCUSSION}

\section{Chemical analysis}

The physico-chemical variations of water in different salinities of fish ponds are shown in Table 1. The source of the dominant nutrient in the ponds was the fish food and possibly fish excretion. Ammonia-N was generally below $40 \mu \mathrm{g}$-at $\mathrm{N} / 1$ and ranged between 14.06 and $35.85 \mu \mathrm{g}$-at $\mathrm{N} / \mathrm{l}$ throughout the sampling period. Maximum allowable concentration of ammonia is $70 \mathrm{mg}$-at $\mathrm{N} / \mathrm{l}$ for aquaculture water (Macdonald, 1994). Nitrate- $\mathrm{N}$ and nitrite $-\mathrm{N}$ concentrations in ponds did not exceed 5 and $2 \mu \mathrm{g}$-at $\mathrm{N} / \mathrm{l}$, respectively at any time during the study period. Phosphate-P concentrations were below $4 \mu \mathrm{g}$-at $\mathrm{P} / \mathrm{l}$ and did not have so much fluctuation between ponds. The flow in the ponds was adjusted to control the concentrations of nutrients and minimize the eutrophication process (Krom and Van Rijn, 1989). This process which results from re-mineralization of detritus accumulated at the bottom of the ponds, it is often followed by unstable water quality that may retard fish growth and occasionally cause mass mortalities (Rimon and Shilo, 1982). After mentioned before, it can conclude that the water quality during the rearing period was suitable and had no harmful effect for all ponds.

Table 1: physico-chemical variations of water in different salinities of fish ponds.

\begin{tabular}{|l|c|c|c|c|}
\hline Pond Parameter & Pond I 40 \%o & Pond II 25 \%o & Pond III 15\%o & Pond IV 5\%o \\
\hline Temperature ${ }^{\circ} \mathrm{C}$ & $23-31$ & $23-31$ & $22-32$ & $23-31$ \\
\hline $\mathrm{pH}$ & $7.82-8.30$ & $8.08-8.54$ & $8.05-8.52$ & $7.89-8.48$ \\
\hline Dissolved Oxygen $\mathrm{mg} / \mathrm{l}$ & $6.55-7.65$ & $6.00-6.68$ & $7.77-8.55$ & $7.53-7.83$. \\
\hline Ammonia $\mu \mathrm{g}-\mathrm{at} / \mathrm{l}$ & $14.06-35.85$ & $16.36-23.99$ & $14.58-35.82$ & $15.07-18.18$ \\
\hline Phosphate $\mu \mathrm{g}-\mathrm{at} / \mathrm{l}$ & $2.02-2.16$ & $2.90-3.14$ & $2.80-3.04$ & $2.82-3.04$ \\
\hline Nitrite $\mu \mathrm{g}-\mathrm{at} / \mathrm{l}$ & $1.00-1.11$ & $1.00-1.04$ & $0.95-1.11$ & $1.03-1.06$ \\
\hline Nitrate $\mu \mathrm{g}-\mathrm{at} / \mathrm{l}$ & $3.86-4.31$ & $4.77-4.81$ & $4.31-4.66$ & $3.91-4.28$ \\
\hline
\end{tabular}

\section{Growth}

Average total weight and total length of the fish at the start of the study were $0.61 \pm 0.19 \mathrm{~g}$ and $4.3 \pm 0.54 \mathrm{~cm}$, respectively. Salinity significantly affected growth of Liza carinata (Fig. 1). Fish reared at salinities $5 \%$ and $40 \%$ exhibited greater growth in length $(\mathrm{cm}) 10.77 \pm 0.097,11.39 \pm 0.088$ and weight $(\mathrm{gm}) 12.3 \pm 0.319,15.02 \pm 0.44$, respectively $(\mathrm{P}<0.05)$. While, fishes at salinities of $15 \%$ and $25 \%$ represented lower growth in length $9.15 \pm 0.23,9.1 \pm 0.10$ and weight $7.41 \pm 0.53,7.83 \pm 0.29$, respectively $(\mathrm{P}>0.05)$. 

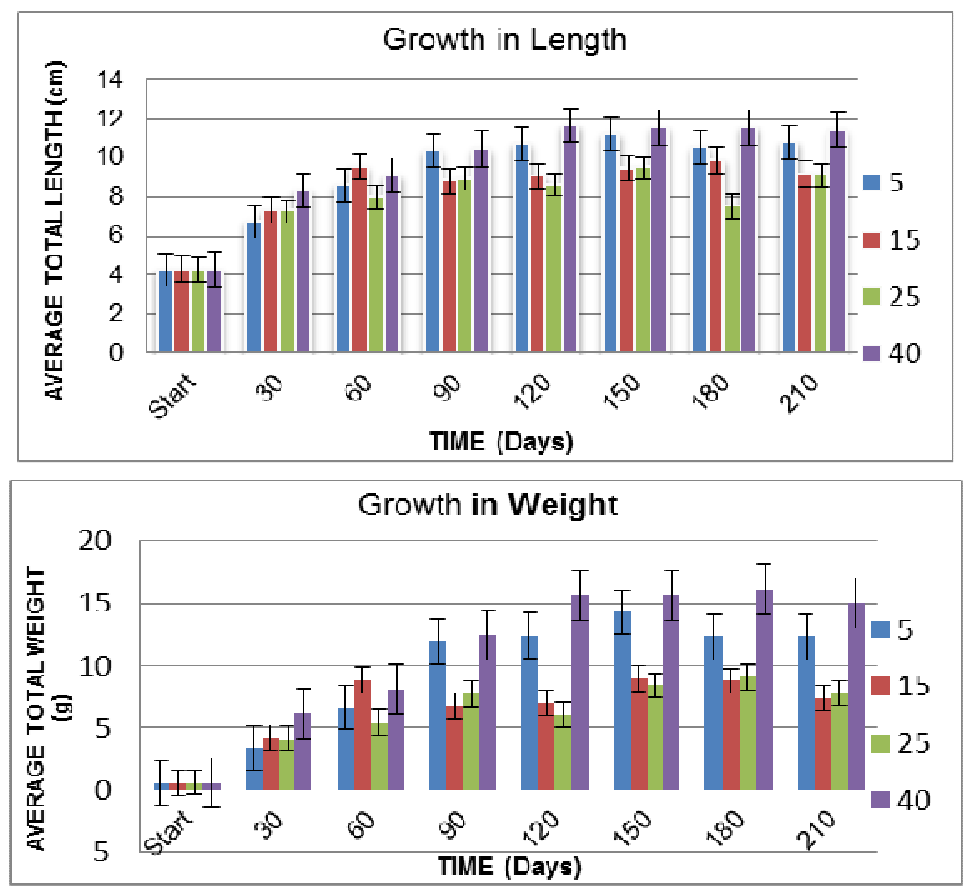

Fig. 1: Growth in total length $(\mathrm{cm})$ and total weight $(\mathrm{gm})$ of Liza carinata reared at four salinities degrees $(5,15,25$ and $40 \%$ o) for 210 days. The vertical bars represented $95 \%$ confidence intervals of average value per pond.

Our results demonstrated that the suitable salinities for growth in length and weight for Liza carinata was $40 \%$ and $5 \%$ o. Salinity of $40 \%$ represented the natural habitat of fish. While the low salinity $(5 \%$ ) performed a considerable growth because of energy saving in osmoregulation process. This explanation was supported by Ferreira et al., 2008. This refers to the reduction of energy as the response of marine fish towards changes in salinity has not been consistent amongst species (Morgan and Iwama, 1996), the importance of salinity should be determined for each aquaculture species. Woo and Kelly (1999) and Boeuf and Payan (2001) suggested that at an isoosmotic salinity of $15 \%$, growth is enhanced in stenohaline fish species, a group of marine species including silver kob. However, these effects are species-specific and need to be evaluated for each species or for fish from different origins. Euryhaline species can be reared at salinities below 35\%o due to their ability to move across salinity gradients (Deacon, 1997). Reduced salinity can decrease the energy demand for osmoregulation in some species and it may play a directing role for the growth of fish by improving their ability to digest and utilise food more efficiently (Resley et al., 2006). Turbot, Scophthalmus maximus, grew faster and their food conversion ratio improved when they were reared at salinities of $12-19 \%$ as compared to the $35 \%$ o salinity of seawater (Lambert et al., 1994, Boeuf and Payan, 2001 \& Imsland et al., 2001). Similarly, red drum, Sciaenops ocellatus, commercially produced under isoosmotic conditions, grew better at a salinity of $11 \%$ o than in seawater (Craig et al., 1995). In the stenohaline Atlantic cod, Gadus morhua, growth at $14 \%$ salinity was better than at 28\%o salinity (Lambert et al., 1994) and wild juvenile whitemouth croaker, Micropogonias furnieri (Sciaenidae), required relatively more metabolic energy at salinities above $20 \%$ when moving through a wide range of salinities (Aristizabal-Abud, 1992). Brown spotted grouper, Epinephelus tauvina, (Akatsu et al., 1983) and European seabass Dicentrarchus labrax, grew best at a salinity of 
25\%o (Dendrinos and Thorpe, 1985). Ferreira et al., (2008) suggested that silver kob can be reared at this salinity (of 25\%o) without negative effects on growth. Also, Saillant et al., (2003) who reported that sea bass growth is high at low salinities.

\section{Condition Factor}

At the end of the rearing period (210 day) the average condition factor did not differ among treatments over all ponds (Table 2). Condition factor was ranging from 0.93 to 1.03 . Condition factor of fish was determined as this variable may reflect recent feeding conditions (Da Costa and Araujo, 2003). This has been suggested as a way to assess the health status of a fish species (Bolger and Connolly, 1989). Since there were no significant differences $(\mathrm{P}<0.05)$ in condition factor of fish that had been subjected to different salinity treatments, it is hypothesised that fish from all treatments consumed and utilized the artificial food equally well at all salinities.

Table 2: Condition factors (K) of Liza carinata, reared at different salinities for 210 days. Data are means \pm SE.

\begin{tabular}{|c|c|c|}
\hline Pond salinity $(\% o)$ & Number of fish & $\mathrm{K}\left(\mathrm{g} / \mathrm{cm}^{3}\right)$ \\
\hline 5 & 44 & $0.98 \pm 0.016$ \\
\hline 15 & 25 & $0.93 \pm 0.012$ \\
\hline 25 & 36 & $1.03 \pm 0.011$ \\
\hline 40 & 25 & $1.01 \pm 0.011$ \\
\hline
\end{tabular}

\section{Gonadosomatic Index (GSI)}

It is obvious that GSI differs among treatments for male and female Liza carinata. Gonadosomatic index was significantly influenced by salinity $(\mathrm{P}<0.05)$. The GSI for both males and females have nearly the same fluctuation trends which reached to the maximum level at salinity of $40 \%$ o for both sexes 8.9 for female and 2.1 for male. The variation of GSI is generally used to indicate the maturity stages and spawning of the fish (Fig. 2). When GSI reaches its maximum value, this gives a perfect indication about the time of spawning. Variations in GSI values were previously detected by Salem and Mohamed (1982) in lake Timsah, El-Boray (1993) in Suez bay, Mahmoud (1997) and El-Halfawy (2004) in different fish farms.

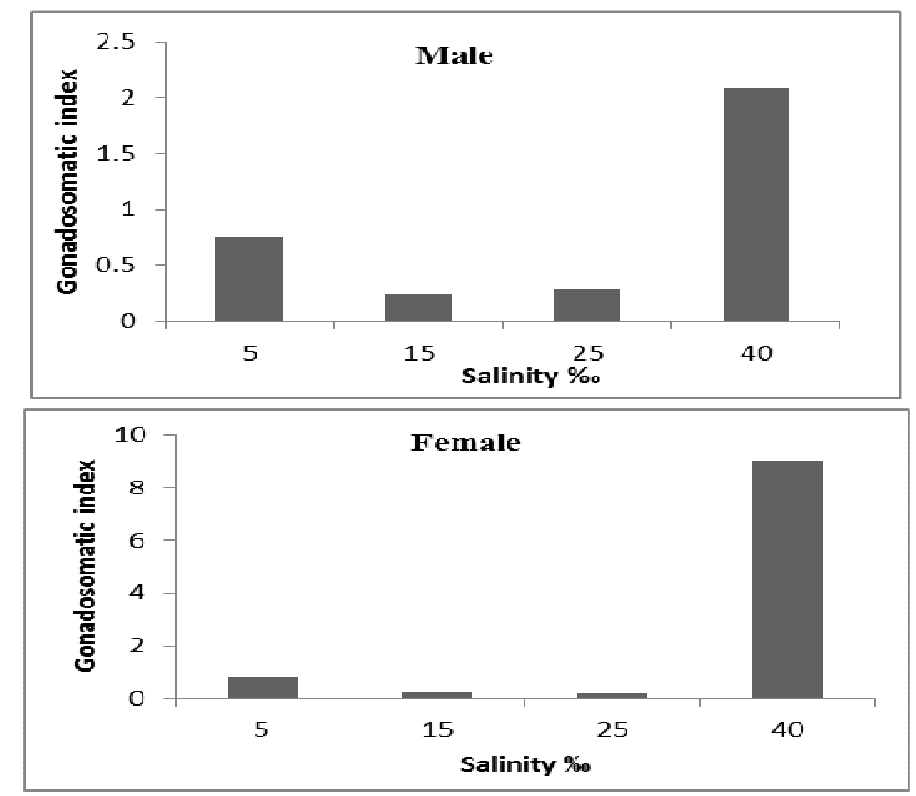

Fig. 2: Gonad somatic index (GSI) of male and female Liza carinata reared in different saline waters $(5,15,25 \& 40 \%)$. 


\section{Length-weight relationship}

Length-weight relationships of fishes are crucial in the fisheries biology and assessment .The sample size, minimum and maximum length and weight, parameters of length-weight relationship (a\&b) and coefficient of determination $R^{2}, \pm 95 \% \mathrm{CI}$ of "b", values are shown in Table (3) and Figure (3). From this table it is evident that highest coefficient " $b$ " were $2.839,2.847$ for fishes at salinities $40 \%$ and $5 \%$, respectively they closed to 3 it is indicated that isometric growth, while "b" less than 3 at salinities $25 \%$ and $15 \%$, values of "b" were 1.512 and 2.323 , respectively that is allometric growth. It is well known that the function of " $\mathrm{b}$ " value represents the body form and it is directly related to the weight affected by ecological factors ,such as temperature, food supply, spawning conditions and other factors, such as sex, age, fishing time and area and fishing vessel (Ricker,1973). In this experiment we established all factors only salinity was change, so may be change in "b" value due to change in salinity and in range of total length and weight between ponds. This result coincides with Salem and Mohamed (1982) and Mahmoud (1997) as they found variations for $b$ values of length weight relationship with different source of water salinity. Also, Sampaio et al., 2001, found that the values of $b$ for the length weight relationship of Brazilian flounder were always near 3 which reared at different salinities.

Table 3: Length weight relationship of Liza carinata, at different salinities during 210 day.

\begin{tabular}{|lccccccc|}
\hline Pond parameter & $\begin{array}{c}\text { Log T.L } \\
\text { Min - Max }\end{array}$ & $\begin{array}{c}\text { Log T.wt } \\
\text { Min - Max }\end{array}$ & $\begin{array}{c}\text { Regression } \\
\text { Ln a }\end{array}$ & b & S.E of" b" & 95\%of CI & $\mathrm{R}^{2}$ \\
\hline Pond I 40\%o & $7.3-12.8 \mathrm{~cm}$ & $3.85-21.71 \mathrm{gm}$ & -1.8207 & 2.839 & 0.062 & $2.714-2.964$ & 0.958 \\
\hline Pond II 25\%o & $4.7-11.3 \mathrm{~cm}$ & $7.9-12.33 \mathrm{gm}$ & -0.577 & 1.512 & 0.181 & $1.152-1.872$ & 0.410 \\
\hline Pond III 15\%o & $4.5-11.5 \mathrm{~cm}$ & $0.91-14.11 \mathrm{gm}$ & -1.369 & 2.323 & 0.119 & $2.086-2.560$ & 0.800 \\
\hline Pond IV 5\%o & $5.9-12.4 \mathrm{~cm}$ & $2.3-18.14 \mathrm{gm}$ & -1.844 & 2.847 & 0.042 & $2.764-2.930$ & 0.975 \\
\hline
\end{tabular}

$\mathrm{n}=$ number of sample, Min=minimum, Max = maximum, $\mathrm{a}=$ intercept of regression line, $\mathrm{b}=$ slope of regression line, $\mathrm{S} . \mathrm{E}=$ Standard Error, $\mathrm{Cl}=$ confidence level, $\mathrm{R}=$ regression coefficient .
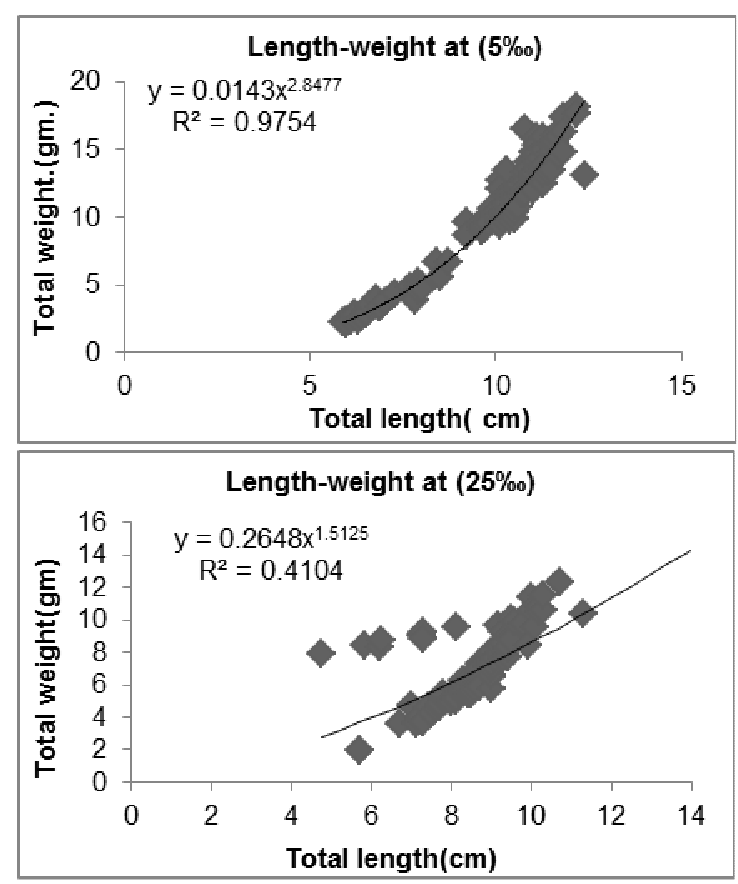
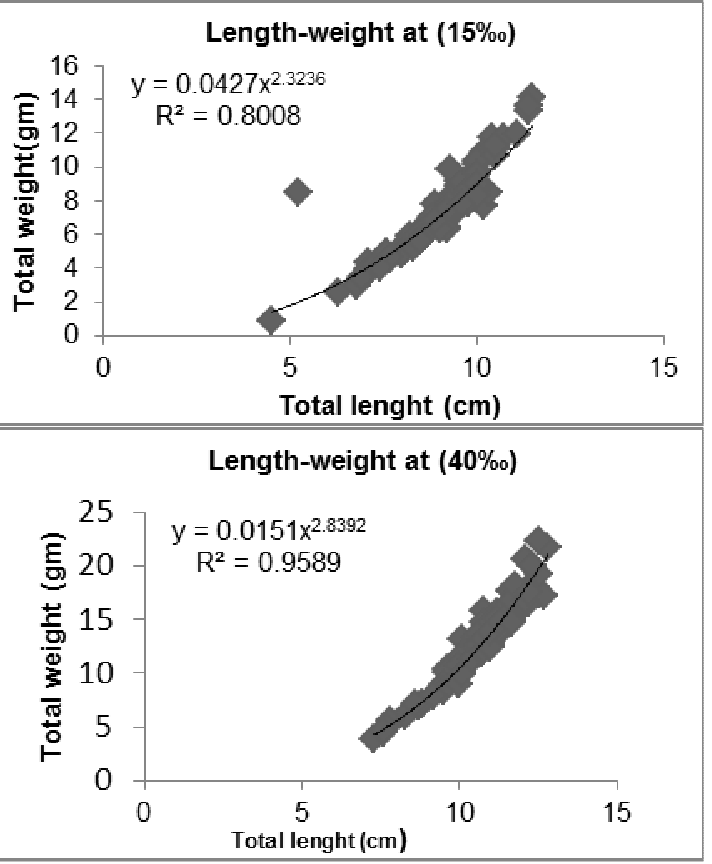

Fig. 3: Length-weight relationship of Liza carinata reared in different salinities. 


\section{Histological features of gonad maturation \\ The female:}

1- Perinucleolar stage (Pond III, $15 \%$ ):

At the beginning of this stage, the oocytes are small and spherical or oval in shape. The cytoplasm increase and becomes greater in volume than the nucleus. Oocytes by the end of this stage vary between tetragonal and polygonal in shape. The nucleoli move to the peripheral position adjacent to the nuclear membrane (Table 4 \& Fig. 4 A).

2- Yolk vesicle stage (Pond IV, 5\%o \& Pond II, 25\%o):

The oocytes were characterized by the appearance of yolk vesicles. As the oocytes develop, the yolk vesicles increase in number and size, gradually filling the cytoplasm from the periphery of the oocyte toward the center and arranged in raws (Table 4 \& Fig. 4 B).

3- Ripe stage (Pond I, $40 \%$ ):

The yolk globules first appear in the outermost part of the ooplasm and gradually increased in number and size as the oocyte grows and the yolk layer continues to become thicker in proportion to the adjacent layer of the cytoplasm. Finally, the larger yolk spheres are apparently formed by the fusion of smaller yolk globules. Moreover, numerous lipid droplets remain in the peripheral part of the yolk mass (Fig. 4 C).

\section{The male:}

1- Immature stage (Pond III, $15 \%$ ):

The completely immature or infantile testes consist of small closely packed cysts or nests of spermatogonia with different diameters. The testes were separated into lobules. The spermatogonia were rounded in shape and varied in number (Table 4 \& Figure 5 A).

2- Mature stage (Pond II, $25 \%$ ):

This stage was characterized by the predominance of spermatozoa overall the earlier cell stages (spermatogonia, primary spermatocytes, secondary spermatocytes and spermatids) present in the lobules. The lumina of the lobules contained a fair amount of sperms and the spermatic duct was full of sperms (Table 4 \& Fig. 5 B). 3- Ripe stage (Pond IV, $5 \%$ \& \& Pond I, $40 \%$ ):

At this stage the lobules and ducts were packed with mature spermatozoa, but the earlier germ cells were fewer and embedded in the lobule walls. The tunica albuginea appeared thin and stretched and the lobules distended to their maximum diameter, and their walls also become thin and stretched. In addition, the seminiferous lobules were separated by thin layer of interlobular connective tissue (Table 4 \& Fig. $5 \mathrm{C})$.

Table 4: Maturity stages of reared Liza carinata in different salinities at the end of experiment.

\begin{tabular}{|c|c|c|c|c|c|c|c|c|}
\hline & \multicolumn{2}{|l|}{ Stage I } & \multicolumn{2}{|l|}{ Stage II } & \multicolumn{2}{|c|}{ Stage III } & \multicolumn{2}{|c|}{ Stage IV } \\
\hline & ㅇ & त & q & $\lambda$ & q & $0^{\pi}$ & 우 & $\hat{0}$ \\
\hline $5 \%$ & & & & & + & + & & + \\
\hline $15 \%$ & & + & + & & & & & \\
\hline $25 \%$ & & & + & & + & + & & \\
\hline $40 \%$ & & & + & & + & & + & + \\
\hline
\end{tabular}

It can be concluded that, the maximum gonadal maturation at salinity $40 \%$ (represents the natural environment of this fish) reached to ripe stage for male and female. Gonadal maturation of salinity 5\%o reached to ripe stage for male and yolk vesicle stage for female (may be attributed to save energy in osmoregulation process). 
Many authors have reported the influence of water salinity on fish development. In Mullet (Mugil sp.) larvae, growth was estimated at 3 to $24 \%$ and the best results in terms of weight increase were recorded 17\%o (Peterson et al., 1999).

There is a wide range of results, but no definitive explanation of the reasons leading to higher or lower growth in different salinities. This conclusion coincides with several studies reported the effects of salinity on growth of fishes (Sampaio et al., 2001). It has been proposed that high rates of protein turnover can result in reduced growth, which can be detected by higher nitrogen excretion rates (Carter et al. 1998).

Thus, in marine fishes like as sea bass larval performances appear to be significantly improved under isotonic conditions, as has also been reported in the rearing of other marine species such as Sparus aurata (Tandler et al., 1995) and Mugil cephalus (Hare et al., 1998). The decreased performances recorded at high salinity during early development may be linked to limits in the osmoregulation capacity during early larval development.

The effects of salinity on growth are complex, vary among species and are not readily predicted (Iwama, 1996). While it is widely accepted that rearing of fish near their iso-osmotic point has an energy saving effect (Gaumet et al., 1995; Boeuf and Payan, 2001), few studies have addressed the effects of increased salinity on growth in true freshwater species. In marine fish, decreasing the salinity towards isoosmolality often increases growth, which is commonly explained by a reduction in energy expenditure associated with ion regulation (Brett, 1979; Jobling, 1995).

\section{CONCLUSION}

It can be concluded that Liza carinata could be reared in low saline conditions (5\%o). It performs the maximum gonadal maturation at salinity 40\%o (represents the natural environment of this fish) reached to ripe stage for male and female. At salinity $5 \%$, gonadal maturation reached to ripe stage for male and yolk vesicle stage for female (may be attributed to the saving of energy in osmoregulation process).

\section{REFERENCES}

Akatsu, S.; Al-Abdul-Elah K. M. and Teng, S. K. (1983). Effects of salinity and water temperature on the survival and growth of brown-spotted grouper larvae (Epinephelus tauvina, Serranid ae). Journal of the World Mariculture Society, 14: 624-635.

Almeida, P. R. (2003). Feeding ecology of Liza ramada (Risso, 1810) (Pisces, Mugilidae) in a south-western estuary of Portugal. Estuar. Coast. Shelf Sci., 57: 313-323.

Aristizabal-Abud E. O. (1992). Effects of salinity and weight on routine metabolism in the juvenile croaker, Micropogonias furnieri (Desmarest 1823). Journal of Fish Biology, 40: 471-472.

Ben Tuvia, A.; Davidoff, E.B.; Shapiro, J. and Shefler, D. (1992). Biology and management of lake Kinneret fisheries. Israeli. Journal Aquaculture-Bamidgeh, 44: 48-65.

Blaber, S.J.M. (1997). Fish and fisheries of tropical estuaries. Chapman and Hall, London. 
Boeuf, G. and Payan, P. (2001). How should salinity influence fish growth? Comparative Biochemistry and Physiology - C Toxicology and Pharmacology, 130: 411- 423.

Bolger, T. and Connolly, P. L. (1989). Selection of suitable indices for the measurement and analysis of fish condition. Journal of Fish Biology, 34:171182.

Brett, J. R. (1979). Environmental factors and growth. In: Hoar WS, Randall DJ and Brett JR (eds) Fish physiology. Vol: III. Academic Press, New York, pp. 599-675.

Cardona, L. (2001). Non-competitive coexistence between Mediterranean grey mullet (Osteichthyes, Mugilidae): evidences from seasonal changes in food availability, niche breadth and trophic overlap. Journal of Fish Biology, 59: 729-744.

Carter, C. C.; Houlihant, D. F. and Owen, S. F. (1998). Protein synthesis, nitrogen excretion and long-term growth of juvenile Pleuronectes flesus. Journal of Fish Biology, 5:272-284.

Craig, S. R.; Neill, W. H. and Gatlin, D. M. (1995). Effects of dietary lipid and environmental salinity on growth, body composition and cold tolerance of juvenile red drum (Sciaenops ocellatus). Fish Physiology and Biochemistry, 14: 49-61.

Da Costa, M. R. and Araujo, F. G. (2003). Length-weight relationship and condition factor of Micropogonias furnieri (Desmarest) (Perciformes, Sciaenidae) in the Sepetiba Bay, Rio de Janeiro State, Brazil. Revista Brasileira de Zoologia, 20: 685-690.

Deacon, N. (1997). Determination of the optimum environmental requirements of juvenile marine fish: the development of a protocol. Ph.D. Thesis, Rhodes University, South Africa.

Dendrinos, P. and Thorpe, J. P. (1985). Effects of reduced salinity on growth and body composition in the European bass Dicentrarchus labrax (L.). Aquacult., 49:333-358.

Eisawy, A. M.; Ishak, A. M. and Hamza, A. (1974). Experimental rearing of two species Mugil cephalus and Mugil capito in Egyptian fish farms. Bulletin of Institute of Oceanography and Fisheries, ARE., 4: 57-96.

EL-Boray, K. (1993). Reproductive biology and physiological characters of Mugil seheli in Suez Bay, M. Sc. Thesis, Faculty of Science. Tanta University.

EL-Halfawy, M. M. (2004). Reproductive Biology of Mugil seheli (Family Mugilidae). Egyptian Journal of Aquatic Research, 30(B), 234-240.

EL-Halfawy, M. M.; Ramadan, A. M. and Mahmoud, W. F. (2007). Reproductive biology and histological studies of the rey mullet, liza ramada, (risso, 1826) in lake timsah, suez canal. Egyptian Journal of Aquatic Research, 33 (1): 434-454.

Ferreira, H. L.; Vine, N. G.; Griffiths, C. L. and Kaiser, H. (2008). Effect of salinity on growth of juvenile silver kob, Argyrosomus inodorus (Teleostei: Sciaenidae). African journal of Aquatic Science, 33 (2): 161-165.

Gaumet, F.; Boeuf, G.; Severe, A.; Le Roux, A.; Mayer-Gostan, N. (1995). Effects of salinity on the ionic balance and growth of juvenile turbot. J. Fish Biology, 47:865-876.

Jobling, M. (1995). Environmental Biology of Fishes. Chapman \& Hall, London, pp. 455.

Hare, M.; Ben Atia, S.; ZIotkin, V. and Tandler, A. (1998). Mass production of grey mullet, mugil cephalus: effects of environmental and nutritional factors on 
larval performance. The 1sraeli Joumal of Aquaculture-Bamidgeh, 50(3): 91-98.

Iglesias, J.; Olmedo, M.; Otero, J. J.; Peleteiro, J. B. and Solorzano, M. R. (1987). Growth, under laboratory conditions, of turbot, Scophthalmus maximus, from the Ría de Vigo (North-West Spain). Marine Biology, 96:11-17.

Imsland, A.K.; Foss, A.; Gunnarsson, S.; Berntssen, M.; FitzGerald, R.; Bonga, S. W.; Van Ham E.; Nævdal, G.and Stefansson, S.O. (2001). The interaction of temperature and salinity on growth and food conversion in juvenile turbot (Scophthalmus maximus). Aquaculture, 198: 353-367.

Imsland, A. K.; Gunnarsson, S.; Foss, A. and Stefansson, S. O. (2003). Gill Na+, K+ATPase activity, plasma chloride and osmolality in juvenile urbot (Scophthalmus maximus) reared at different temperatures and salinities. Aquaculture, 218:671-683.

Iwama, G. K. (1996). Growth of salmonids. In: Pennell, W., Barton, B.A. (Eds.), Principles of Salmonid Culture. Elsevier, Amsterdam, Netherlands, pp. 467-516.

Krom, M. D. and Van Rijn, J. (1989). Water quality processes in fish culture systems; Processes, problems and possible solution. In: de Pawn, N., Jaspers, E., Ackefors, H. and Wilkins, N. (eds),Aquaculture-A biotechnology in progress.European Aquaculture Society, Bredene, Belgium.pp. 1-21.

Laffaille, P.; Brosse, S.; Feunteun, E.; Baisez, A. and Lefeuvre, J. C. (1998). Role of fish communities in particulate organic matter fluxes between salt marshes and coastal marine waters in the Mont Saint-Michel Bay. Hydrobiologia, 373/374:121-133.

Laffaille, P.; Feunteun, E.; Lefebvre, C.; Radureau, A.; Sagan, G. G. and Lefeuvre, J. C. (2002). Can thin-lipped mullet exploit the primary and detritic production of European macrotidal salt marshes? Estuar. Coast. Shelf Sci., 54: 729-736.

Lambert, Y.; Dutil, J. D. and Munro, J. (1994). Effects of intermediate and low salinity conditions on growth rate and food conversion of Atlantic cod (Gadus morhua). Canadian Journal of Fisheries and Aquatic Science, 51: 1569-1575.

Mahmoud, W. F. (1997). Reproductive and physiological characters of Mugil seheli in fish farms. M. Sc. Thesis, Faculty of Science, Suez Canal University.

MacDonald, D.D. (1994). A review of environmental quality criteria and guidelines for priority substances in the Frazer River Basin: A summary of available water quality criteria and guidelines for protection of aquatic life. MacDonald Envir. Sci. Ltd., http:// bordeaux.uwateloo.ca/bio1447/waterquality/aquaticlife.

McDowall, R.M. (1988). Diadromy in fishes. Migrations between freshwater and marine environments. Croom Helm, London.

Morgan, J. D. and Iwama, G. K. (1996). Cortisol-induced changes in oxygen consumption and ionic regulation in coastal cutthroat trout (Oncorhynchus mykiss). Fish Physiology and Biochemistry, 15: 385-395.

Parsons, T. R.; Maita, Y. and Lalli, C. M.. (1984). A manual of chemical and biological methods for seawater analysis. Pergamon Press, New York. 170 pp.

Peterson. M.S.; Comyns, B. H. H.; Rakocinski, C. F. and Fulling, G. L. (1999). Does salinity affect somatic growth in early juvenile Atlantic croaker, Micropogonias undulatus (L.) Journal of Experimental Marine Biology and Ecology, 238: 199-207.

Pombo, L.; Elliott, M. and Rebelo, J. E. (2005). Environmental influences on fish assemblage distribution of an estuarine coastal lagoon, Ria de Aveiro (Portugal). Sci. Mar., 69: 143-159. 
Ravagnan, G. (1992). Vallicoltura integrata. Edagricole, Bologna.

Resley, M. J.; Webb, K. A. and Holt, G. J. (2006). Growth and survival of juvenile cobia, Rachycentron canadum, at different salinities in a recirculating aquaculture system. Aquaculture, 253: 398-407.

Ricker, W. E. (1973). Linear regression in fisheries research. J. Fish. Res. Board Can., 30: 409-434.

Rimon, A. and Shilo, M. (1982). Factors which affect the intensification of fish breeding in Israel. 1.Physical, chemical and biological characteristics of intensive fishponds in Israel. Bamidge, 34: 87-100.

Saillant, E.; Fostier, A.; Haffray, P.; Menua, B. and Chatain, B. (2003). Saline referendum for the European sea bass, Dicentrarchus labrax, larvae and juveniles: effect of salinity on early development and sex determination. J. Exp. Mar. Biol. Ecol., 287: 103-117.

Salem, S. A. and Mohamed, S. Z. (1982). Studies on Mugil seheli and M. capito in Lake Timsah. I. Age and growth. Bull. Inst. Oceanogr. \& Fish. RAE, 8 (1): 49-68.

Sampaio, L. A.; Adalto, B. and Vinicius, R. C. (2001). Growth of juvenile Brazilian Flounder, Paralichthys orbignyanus cultured at different salinities. Journal of Applied Aquaculture, 11(1/2): 67-75.

Tandler, A.; Anav, F. A. and Chosniak, I. (1995). The effect of salinity on growth rate, survival and swimbladder inflation in gilthead seabream, Sparus aurata, larvae. Aquaculture, 135: 343-353.

Torras, X.; Cardona, L. and Gisbert, E. (2000). Cascading effects of flathead grey mullet Mugil cephalus of the ecosystem of eutrophic freshwater microcosmos. Hydrobiologia, 429: 49-57.

Winkler, L.W. (1976). .Berdtsch.Chem. Ges., 22:1764-1774.

Woo, N. Y. S. and Chung, K. C. (1995). Tolerance of Pomacanthus imperator to hypoosmotic salinities: changes in body and hepatic enzyme activities. Journal of Fish Biology, 47: 70-81.

Woo, N.Y.S and Kelly, S.P. (1999). Effects of salinity and nutritional status on growth and metabolism of Spams sarba in a closed seawater system. Aquaculture, 135: 229-238.

Wootton, R.J. (1990). Ecology of teleost fishes. Chapman and Hall, London. 


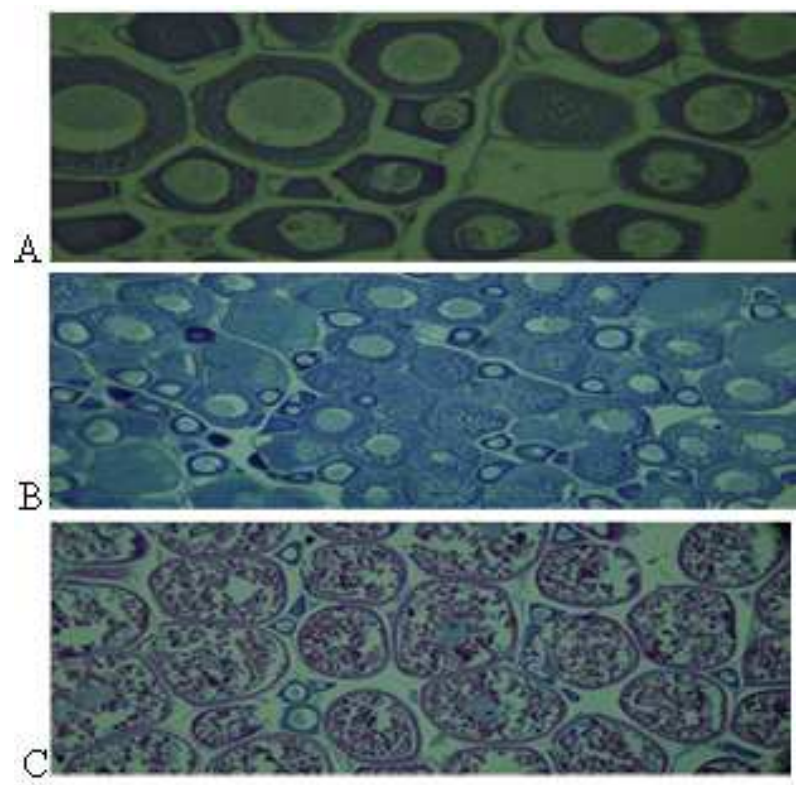

Fig. 4: Photomicrographs of transverse sections of the ovary (at maximum maturation stage) of Liza carinata reared in different water salinities:

A- Perinucleolar stage (15\%). H. \& E., X 80.

B- Yolk vesicle stage (5\% \& $25 \%)$. H. \& E., X 20.

C- Ripe stage (40\%). H. \& E., X 40.
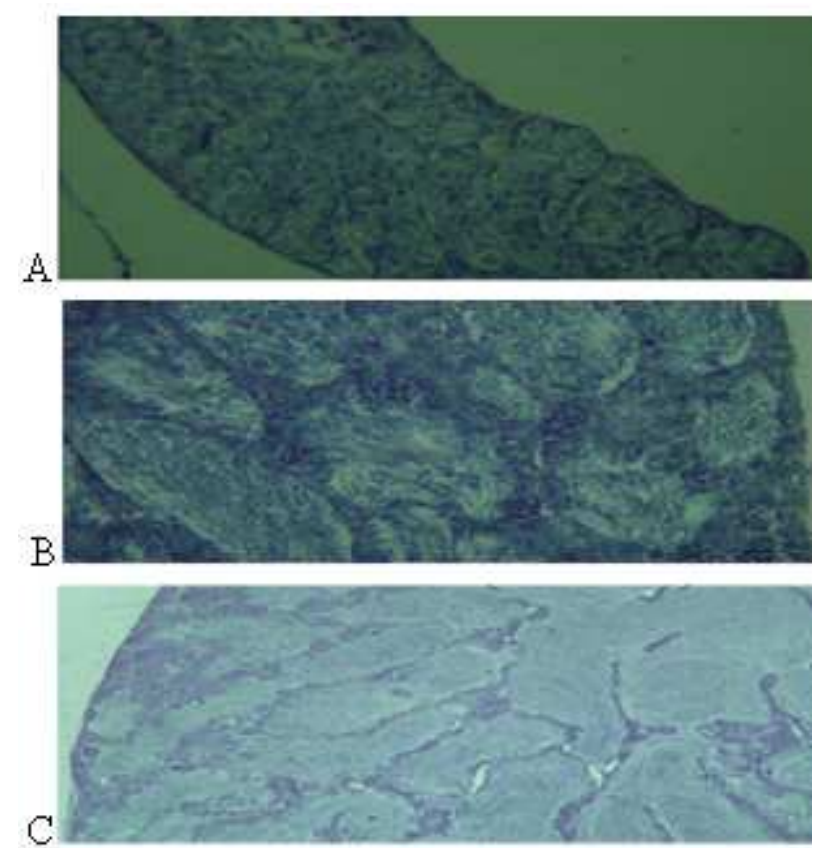

Fig. 5: Photomicrographs of transverse sections of the testis (at maximum maturation stage) of Liza carinata reared in different water salinities:

A- Immature stage (15\%). H. \& E., X 100.

B- Mature stage $(25 \%)$. H. \& E., X 80.

C- Ripe stage (5\% \& $40 \%$ ). H. \& E., X 40. 


\section{Arabic Summary}

نمو ونضج المناسل لسمكة السهلية المستزرعة فى درجات الملوحة المختلفة

كمال فتحى البرعى - مجدى مصطقى الحلفاوى - وحيد فرج الله محمود ـ أمل محمد أمين

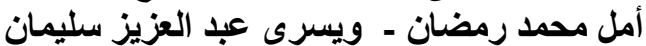

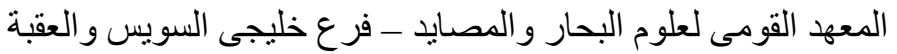

4 X5) تم أجر اء تجربة استزراع سمكة السهلية وتأثير الملوحة عليها فى أحو اض أسمنتية حجمها

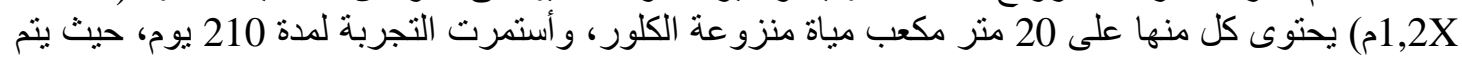

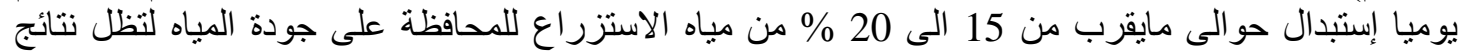

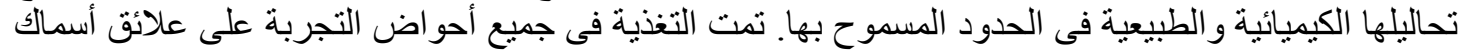

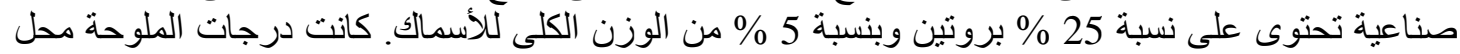

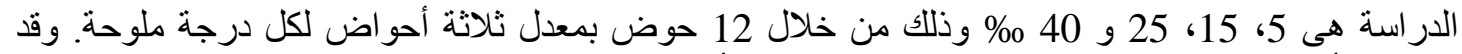

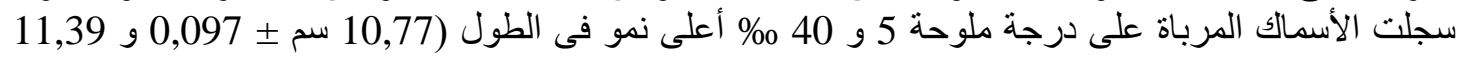
سم ـ 0,088) وكذللك الوزن (12,3 جم ـ

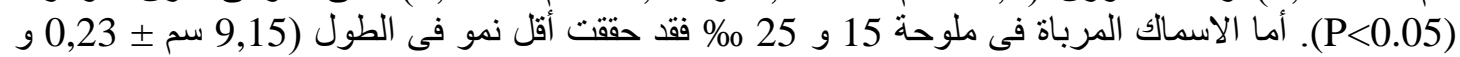

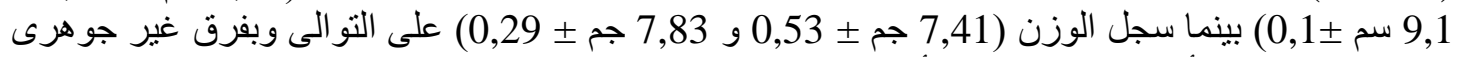

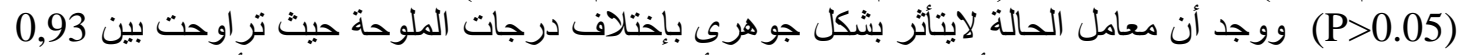

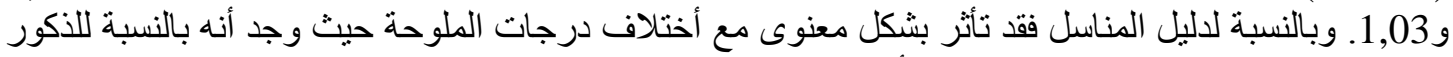

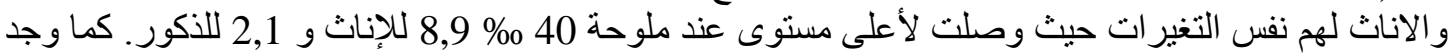

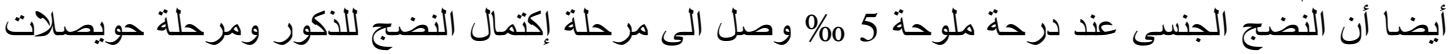

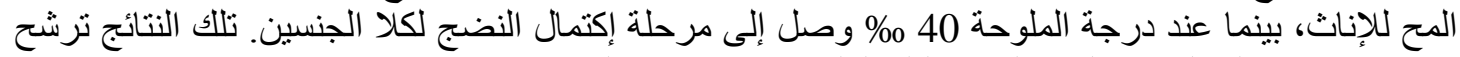
إستزر اع سكة السهلية فى المياة العسر قليلة الملوحة و هذا يؤدى الى توفير نفقات إستزر اعها. 